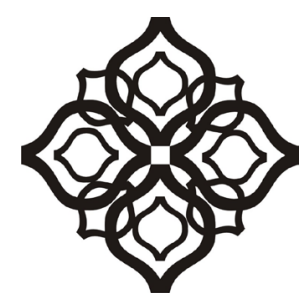

Shirkah

Journal of Economics and Business 


\section{Shirkah}

Journal of Economics and Business

Vol. 2, No. 2, May-August 2017

ISSN: 2503-4235 (p); 2503-4243 (e)

\section{Editor in Chief}

Sri Walyoto

\section{Editorial Boards}

Abu Umar Faruq Ahmad, UBD School of Business and Economics, Brunei Darussalam

Amelia Fauzia,

Asia Research Institute, National University of Singapore, Singapore

Cedomir Nestorovic,

ESSEC Business School Asia Pacific, Singapore

Dwi Condro Triono,

Faculty of Islamic Economics and Business, IAIN Surakarta, Indonesia

Fahmy Radhi,

Faculty of Economics and Business Universitas Gadjah Mada, Yogyakarta,

Indonesia

Hasan Basri,

Syiah Kuala University, Aceh, Indonesia

Johan Fischer,

Department of Social Sciences and Business Roskilde University, Denmark

Masudul Alam Choudhury,

Postgraduate Program in Islamic Economics and Finance, Trisakti University,

Jakarta, Indonesia and the College of Economics and Political Science (CEPS) in

Sultan Qaboos University (SQU), Oman

M. Falik Isbah,

School of Humanities and Social Science, University of New South Wales, Australia M. Ishaq Bhatti,

La Trobe Business School Department of Economics and Finance La Trobe

University, Australia

Najib Kailani,

Pascasarjana, Universitas Islam Negeri (UIN) Sunan Kalijaga, Yogyakarta, Indonesia 
Nunung Nurul Hidayah,

Aston Business School, Aston University, Birmingham, United Kingdom

Shaikh M Ghazanfar,

Departement of Economics, University of Idaho, Russian Federation

\section{Managing Editors}

Fitri Wulandari

Jasanta Perangin-angin

\section{Assistant to Editor}

M. Endy Saputro

M. Zainal Anwar

Supriyanto

Shirkah Journal of Economics and Business is a peer-reviewed journal published three times a year (January-April, May-August and September-December) by Faculty of Islamic Economics and Business, Institut Agama Islam Negeri (IAIN/ State Institute for Islamic Studies) Surakarta Central Java, Indonesia. The main objective of Shirkah is to offer an academic space of exchange ideas and initiate the increase number of qualified article produced by postgraduate students, practitioners and academicians.

\section{Editorial Office}

Ruang Jurnal Shirkah

Ground Floor, West Gate,

Faculty of Islamic Economics and Business

IAIN Surakarta

Jln. Pandawa No. 1, Kartasura, Sukoharjo, Jawa Tengah Kode Pos. 57168

Phone (+62271) 781516 Fax: (+62271)782336

E-mail: shirkahiainsurakarta@gmail.com

Website: http://shirkah.or.id/ 


\section{Shirkah}

Journal of Economics and Business

Vol. 2, No. 2, May-August 2017

ISSN: 2503-4235 (p); 2503-4243 (e)

\section{Table of Contents}

\section{Articles}

Shairil Izwan Taasim

Ramali Yusoff

An Instrument Developing Cashless in Malaysia

Aam S. Rusydiana

Irman Firmansyah

Efficiency versus Maqasid Sharia Index An Application on Indonesia

Islamic Bank

Azhar Ibrahim

The Call for Islamic Economics Shades of Contestation

Warsono

Deferred Tax Assets and Deferred Tax Expense Against Tax Planning Profit Management

Lisdawati Arifin

Earning on Response Coefficient in Automobile and Go Public

Companies

Farihatul Qamariyah

Waroeng Steak: Spritual Company in the Context of Post-Capitalism 


\title{
Deferred Tax Assets and Deferred Tax Expense Against Tax Planning Profit Management
}

\author{
Warsono \\ Faculty of Economics and Business, University of Pancasila
}

\begin{abstract}
The purpose of this study is to examine the probability of earnings management performed by Property and Real Estate companies listed in Indonesia Stock Exchange (BEI) in the period 2011-2015. How to do the management to influence the accounting numbers can be either profit management through deferred tax assets, deferred tax expense and tax planning in the financial statements. This paper examines the effect of deferred tax assets deferred tax burden, and tax planning to earnings management conducted by the company. Data of the research is to use secondary data from company financial statements that were downloaded from the official website of Indonesia Stock Exchange. Using sampling technique is performed by purposive sampling. The study population is the Property and Real Estate companies listed in Indonesia Stock Exchange in the period 2011-2015. The study take sample as many as 34 companies Property and Real Estate in the Stock Exchange in 2011-2015. Hypothesis testing uses multiple regressions with SPSS software version 22 o'clock. The result shows that the Deferred Tax Assets positive and significant effect on earnings management; while deferred tax expense and tax planning significant negative effect on earnings management.
\end{abstract}

Keywords: Assets, Deferred Tax Expense, Tax Planning, Profit Management

\section{Introduction}

Information profit as stated in the Statement of Financial Accounting Concept (SFAC) No. 2 has primary been a key element in the financial statements and very important, to make the management tried to make earnings management so that the company's performance look 
good by external parties. Managers tend to favor earnings management policy by controlling the accrual transaction. Mulford and Comiskey (2010) defined as the manipulation of accounting earnings management with the aim of creating the company's performance in order to look better than it actually is (Dhamija, 2017). Earnings management can occur for the preparation of financial statements using accrual basis provides an opportunity for managers to issue accounting considerations which will impact on reported earnings (Gao, 2017; Chiwamit, 2017; Meiseberg, 2017). In this case the revenue can be manipulated through discretionary accruals (Gumanti, 2000). Accrual earnings management can be measured by discretionary accrual models with modified Jones modified by Kothari et al. (2005) which was later defined by Tucker and Zarowin (2005). Discretionary accruals is a model that is used by management to practice leveling profit, while according Syahril (2016) emerged from earnings accrual management accounting (accrual) as tesa with anti tesa earnings management as accrual management childbirth.

Managers who rely on accrual earnings management alone will be at risk if the realization of the end of the year the deficit between income that is not manipulated by the desired profit target exceeds the amount allowed to manipulate accruals after the end of the fiscal period (Roychowdhury, 2006; Gianni, 2017; Brown, 2017; Bettinazzi, 2017). Profit targets are not achieved are considered managers do not have a good performance, so the opportunity to get compensation will be lost even can lead to the dismissal of manager. View of agency theory that the separation between the principal and the agent that causes the appearance of potential conflict that could affect the quality of reported earnings (Rehman, 2017). Intent with principals in the agency theory is that the shareholders or owners of the facilities and funds for the needs of the company's operations while the agent is a management company that has the obligation to manage as it has been entrusted to him by Sanjaya principal and Sulistyanto (2004). 
Positive accounting theory predicts such actions related to the accounting policy choice by the manager of the company and how the manager's response to a proposed new accounting standard Scott (2003). According to Watts and Zimmerman (1990), positive accounting theory that seeks to explain the observed phenomenon of accounting based on the reasons that led to the occurrence of an event. Ghozali and Chariri (2011) states that the stakeholder theory the company is not an entity that only operates for its own account but must provide benefits to stakeholders (shareholders, creditors, customers, suppliers, government, community, corporate analysts, and other parties. Gray et al (1995) states that the company's survival depends on the support of stakeholders. According to Waluyo (2014), the deferred tax assets (deferred tax asset) is the amount of income tax recoverable (recovered) in future periods as a result of deductible temporary differences and the rest of the losses can be compensated.

PSAK No. 46 mentioned that if the taxable temporary differences are not adequately dealing with the departments of taxation are the same and the company, the deferred tax assets are recognized to the extent it is probable the company has taxable income sufficient relating to service tax and the same company in the same period, as opposed to temporary differences deductible. Burgstahler, et al. (2002) examined the effect of deferred tax assets on earnings management during 1993-1998 to 482 companies. The results showed that the deferred tax asset has a significant influence on earnings management. Research Frank and Rego (2006) examined 2,243 companies to determine the effect of deferred tax assets on earnings management during the years 1993-2002. The results showed that the deferred tax asset has a significant influence on earnings management (Dewi and Fenny, 2011).

Managers utilize deferred tax assets in the commercial financial statements to earnings management, so this may impact on the financial 
statements of the fiscal (Widiastuti and Chusniah, 2011).Various studies on the deferred tax asset with a causal design, as described above gives different results. Likewise, Singkianti study (2015) that uses the construct of the influence of the deferred tax asset or assets to earnings management. The research results confirm that the deferred tax assets do not have a significant effect on earnings management. Study with similar results was also done by Arista (2013). Waluyo (2014) states that the deferred tax expense is the amount of expense (income) Deferred tax arising from the recognition of deferred tax liabilities or assets. While according Phillips, et al. (2003), the deferred tax expense is expense arising from temporary differences between accounting profit. Phillips et.al (2003) found that the deferred tax expense can be used to predict the earnings management practices by management. Meanwhile, according to the manager as the manager of the company will maximize corporate profits led to the process of maximizing their interests at the expense of the owner of the company. This may occur because the manager has information not owned by the owner of the company (Yuliana, 2008; Dickinson, 2017; Kianto, 2017).

Net deferred liabilities obtained from the difference between deferred tax liabilities to deferred tax assets according to Jamaluddin, et al (2008). Suandy (2008) revealed that if in the future there will be a larger payout, based on GAAP to be recognized as a liability. Agoes and Trisnawati (2007) revealed that this deferred tax liability occurs when the fiscal reconciliation in the form of a negative correction, where the commercial accounting income greater than fiscal accounting and expenditure in accordance with commercial accounting smaller than the fiscal accounting. Yulianti (2005), Abdul Rafay and Mobeen Ajmal (2014), Justice and Praptoyo (2015) find empirical evidence that the deferred tax expense had a significant positive correlation with the probability of the company to manage earnings. Philip et al. (2003), Yulianti (2005) and 
Yana Ulfa (2013) conducted tests on deferred tax expense in identifying earnings management.

Yin and Cheng (2004) argues that the company's efforts to minimize tax payments are limited by tax planning. Plan Tax is one form of tax management functions in an effort to to save tax legally (Ompusunggu, 2011), while by Erly Suandy (2011), argue as follows: "Tax planning is a systematic analysis of various different tax election, which aims to minimize liabilities in the current year for the coming period”. In general, tax planning (tax planning) refers to the reverse process and transaction business taxpayer that the tax debt is in a minimal amount, but still within the framework of tax regulations. Sumomba and Hutomo (2012) in his research drew the conclusion that tax planning can be used to detect earnings management, it is because management has always been to respond to changes in tax rates, both the increase in tax rates or reduction in tax rates that are considered by management as an opportunity "gold" to give profit for the company either in the period and future periods. Relate research, such as Anggreani (2013), states tax planning significant effect on earnings management, due to the tax planning used by companies to minimize tax payments so that enterprises receive tax advantages. Similarly, according to Ulfa (2013), the positive effect of tax planning, tax planning means that the higher the more likely companies conduct earnings management.

A phenomenon that occurs late in the property and real estate business is very interesting to observe as the 2008 global financial crisis, as quoted by Suherman starting from the United States due to the subprime mortgages spread throughout the world who also have an impact on the business of Real Estate Property and Indonesia. However this did not dampen the development of the Property and Real Estate business to continue to expand. Expansion Property and Real Estate business of the post-crisis years 2003 to 2008 continues to increase, Property and Real 
Estate in 2009 the government will make a breakthrough policy to open a wider access for foreign investors to get into the property business in Indonesia. Manager requires judgment and estimates related to future value in the financial statements. Rate and these estimates provide flexibility to the manager in preparing the financial report that regulated under SFAS No. 1 for the preparation of accrual-based financial statements (accrual basic). The flexibility provided gives room for managers to manage earnings. SFAS No. 46 gives freedom to the management in determining accounting policy choice in determining the amount of provisioning expenses/ deferred tax income. Backup expenses/ deferred income taxes are the result of differences between the recognition of accounting standards with the tax regulations. Implications of SFAS No. 46 associated with earnings management issue has not been empirically tested in Indonesia. It is in turn necessary to question of whether deferred tax assets, deferred tax expense and tax planning effect on earnings management employed by the company. Based on the previous studies, the authors put forward the hypothesis that the deferred tax assets, deferred tax burden, and tax planning has a significant influence on earnings management. Deferred tax assets, deferred tax expense and tax planning will provide positive implications for reduction of accrual earnings management. 


\section{Designing Profit Management}

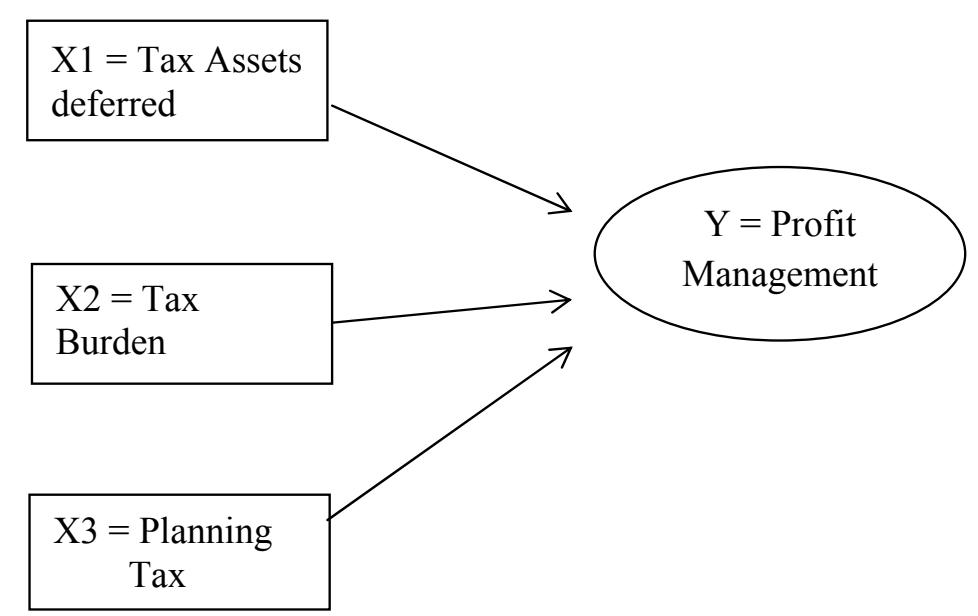

Based onthe characteristics of the problem and the data, this type of research had applied quantitative research methods and the research design causality, emphasizing on management accrual earnings by relying on proxy discretionary accruals, discretionary accrual of this study using the modified Jones modified by Kothari et al. (2005). Population of this research is company property sector of the manufacturing sector and real estate listed on the Stock Exchange over the period 2011-2015. The samples used were industrial sector manufacturing companies and real estate properties that have met the criteria set by the researchers. The sampling method used was purposive sampling.

Deferred Tax Asset (X1), according to Waluyo (2014) states that the deferred tax assets (deferred tax asset) is the amount of income tax recoverable (recovered) in future periods as a result of deductible temporary differences and the rest of the losses can be compensated.In this study as a deferred asset meansured independent variables to changes in the value of deferred tax assets at end of period t to $\mathrm{t}-1$ divided by the value deferred tax assets at end of period t.: 


$$
D T A_{i t}=\frac{\Delta \text { Deferred } \operatorname{Tax} \text { Asset } i_{t}}{\text { Asset Deferred Taxt }}
$$

Deferred Tax Expense (X2), according to Phillips, et al. (2003), the deferred tax expense is expense arising from temporary differences between accounting profit (ie profit in the financial statements for the benefit of external parties) taxable income (income that is used as the basis for calculating tax). Deferred tax expense uses weighting indicator deferred tax expense by total assets or total assets. Weighting deferred tax expense by total assets at period $\mathrm{t}-1$ to obtain the value that is calculated by proportional. Based on Phillips findings (2003), in this study, a deferred asset had been measured with independent variables to changes in the value of deferred tax assets at end of period t to $t-1$ divided by the value deferred tax assets at end of period t.:

$$
D T E_{i t}=\frac{D T E_{i t}}{T A_{i, t-1}}
$$

Information:

DTEit $=$ deferred tax expense of firm $\mathrm{i}$ in year $\mathrm{t}$

Tai, $\mathrm{t}-1=$ Total assets of company $\mathrm{i}$ in year $\mathrm{t}-1$.

Tax Planning (X3), is a strategy undertaken by the company to minimize the tax burden in the year to walk or in the coming year in order to reduce the burden of taxes to be paid, but still within the framework of tax regulations. Measurement of Tax Planning can be done by the following formula according to Wijaya and Martani (2011):

Information:

$$
\text { TAX PLAN }=\frac{\sum_{t}^{t-1}\left(\boldsymbol{T P}_{\boldsymbol{t}} \cdot P T I-C T E\right) / 4}{\boldsymbol{T A}}
$$


TAX PLAN : Tax Planning

PTI : Pre-tax income (Earnings before taxes)

CTE : Current portion of total tax expence (Now the tax burden)

TP : The tax rate

TA : Total assets

Profit Management (Y), this study uses a modified discretionary accrual by Jones modified by Kothari et al. (2005); it have widely been used in studies of accounting due to its model in detecting earnings management and provide the most robust results. Similarly, aggregate accruals-based earnings management to another, this model uses discretionary accruals as a proxy for earnings management.

\section{Tacit $=\boldsymbol{\alpha 0}(1 /$ Assetit-1 $)+\boldsymbol{\beta} 1[(\Delta$ Salesit $-\Delta$ Recit $) /$ Assetit-1 $]+\boldsymbol{\beta} 2$ (PPEit / Assetit-1) + B3 ROAit-1 + Eit}

Information:

tacit = Total accruals for firm $\mathrm{i}$ in year $\mathrm{t}$

Assetit-1 = Logarithm of total assets of the company $\mathrm{i}$ in year $\mathrm{t}-1$

$\Delta$ Salesit $=$ Changes in sales of firm $\mathrm{i}$ in year $\mathrm{t}$ to the year $\mathrm{t}-1$

$\triangle$ ARecit $=$ Changes in trade receivables firm $\mathrm{i}$ in year $\mathrm{t}$ to the year $\mathrm{t}-1$

PPEit = Value of fixed assets on a firm $\mathrm{i}$ in year $\mathrm{t}$

ROAit-1 = Ratio Return on Assets in firm i in year $\mathrm{t}-1$

$\Delta \beta 1 \beta 2=$ Estimated non-discretionary accruals

cit $\quad=$ error term

Total accruals on the model derived from the calculation:

tacit = Operating Incomeit - CFOit

Information:

TACit = Total accruals for firm $\mathrm{i}$ in year $\mathrm{t}$

CFOit = Logarithm of total assets of the company $\mathrm{i}$ in year $\mathrm{t}-1$ 
Non Discretionary Accrual (NDAC) is the predicted value or a fitted value of the above models, and Discretionary Accrual (DAC) is the difference of total Accrual (TAC) with Non Discretionary Accrual (NDAC). Here is the calculation:

\section{DACit $=$ TACit - NDACit}

Information:

DACit = Discretionary Accrual firm $\mathrm{i}$ in year $\mathrm{t}$

TACit $=$ Total accruals for firm $\mathrm{i}$ in year $\mathrm{t}$

NDACit = Non Discretionary Accrual $\mathrm{i}$ in year $\mathrm{t}$

Types and sources of data used in this study using secondary data types and sources. Secondary data used in the form of financial statements of companies manufacturing sector and Real Estate Property went public and listed on the Stock Exchange in the year 2011-2015 has been published. Testing the hypothesis in this study using multiple linear regression. Linear regression model equation used is as follows:

$$
\mathrm{Y}=\mathrm{a}+\beta 1 \mathrm{X} 1+\beta 2 \mathrm{X} 2+\beta 3 \mathrm{X} 3+\mathrm{e}
$$

The population used in this study is the industrial sector manufacturing companies Property and real estate listed on the Stock Exchange in the period 2011 - 2015, with a total population of 34 companies. The sample size amounts to 34 companies for 5 years so that data is processed amounted to 104 data.

\section{Each Variable Significantly}

Testing the hypothesis in this study uses linear regression analysis. Hypothesis test in this study aims to examine the effect of variable deferred tax assets, deferred tax expense and tax planning to earnings management by using multiple linear regression and the results are shown in Table 1 . 
Table 1 shows the significance of each independent variable in influencing the dependent variable. The significant value of each variable compared to the alpha level of $5 \%(\alpha=0.05)$. If the value of the significance of each variable below 0.05 the independent variable on the probability of the dependent variable occur.

Table 1. Hypothesis Test Results

Coefficientsa

\begin{tabular}{|c|c|c|c|c|c|c|}
\hline & \multirow{2}{*}{$\begin{array}{l}\text { Model } \\
\text { B }\end{array}$} & \multicolumn{2}{|c|}{$\begin{array}{c}\text { Coefficients } \\
\text { unstandardized }\end{array}$} & \multirow{2}{*}{$\begin{array}{l}\text { standardized } \\
\text { Coefficients }\end{array}$} & \multirow[t]{2}{*}{$\mathrm{T}$} & \multirow[t]{2}{*}{ Sig. } \\
\hline & & Std. Error & beta & & & \\
\hline \multirow[t]{4}{*}{1} & (Constant) & 27325 & .473 & & 5806 & .000 \\
\hline & APT & 1,482 & .225 & .033 & 2393 & .005 \\
\hline & $\mathrm{CPM}$ & -161484 & 27564 & -.495 & -5858 & .000 \\
\hline & TP & -1714 & .000 & -.220 & -2603 & .011 \\
\hline
\end{tabular}

a. Dependent Variable: EM

Source: Data processed

Table 1 shows the significant value of each variable in the test Statistics. Test each linear regression coefficient as follows: the coefficient variable load deferred tax assets and a significant positive effect. Variable deferred tax expense a significant negative effect. Variable tax planning has no significant negative effect. The regression equation formed from this study is:

$$
\mathrm{EM}=27.325+1,482 \mathrm{DTE} \mathrm{t} \text { APT- } 161.484-1.714 \mathrm{TP}
$$

\section{Effect of Variable against Each Profit Management}

This research is the study of earnings management and usefinancial variables such as deferred tax assets, deferred tax expense, tax planning. This study was conducted using 34 manufacturing company property and real estate sector into the sample through purposive sampling techniques. 
This study covers the period 2011 to 2015 (5 years). Hypothesis testing is done by using multiple linear regression. A summary result of hypothesis testing that has been done is stated in Table 2 .

Table 2. Summary of Results of Testing Hypotheses

\begin{tabular}{|c|l|c|}
\hline No. & \multicolumn{1}{|c|}{ Hypothesis } & result \\
\hline 1 & $\begin{array}{l}\text { Acetate Deferred tax effect on earnings } \\
\text { management }\end{array}$ & Support \\
\hline 2 & $\begin{array}{l}\text { Deferred Tax Expense effect on earnings } \\
\text { management }\end{array}$ & Support \\
\hline 3 & Tax Planning effect on earnings management & Support \\
\hline
\end{tabular}

Source: Data processed

Hacyl hypothesis testing indicates that the deferred tax expense and a significant negative effect on earnings management. The existence of IAS 46 which regulates the company's deferred tax does not guarantee not to perform earnings management. Deferred tax expense arisen from temporary differences between accounting income with taxable profit. The difference between the accounting and fiscal financial statements resulting in the preparation of financial statements, accounting standards give more flexibility for managers to determine the methods and estimates than allowed under the tax. This makes managers take advantage of gaps to manipulate the amount of deferred tax expense owned (Yulianti, 2005). The large amount of deferred tax expense reduces corporate profits, thereby takes effect on the amount of tax to be paid.

Based on this fact, the planning had been done through two mechanisms to get the lower of the profit before tax. If the company acquires revenue/ huge revenue it will generate big profits. With this condition, the company will make tax planning are greater. Companies with a payment they will tend to seek a decrease in the value of corporate 
profits through discreonary accrual. Put it simply when planning increases, the company will reduce the value discreonary which is a proxy of earnings management, therefore it take the negative effect of tax planning.

\section{Conclusion}

Based on analysis of the three hypotheses testing, it concludes that deferred tax assets and take a significant positive effect on earnings management by the company manufacturing industry sector property and real estate listed on the Stock Exchange; deferred tax expense and take a significant negative effect on earnings management by the company manufacturing industry sector property and real estate listed on the Stock Exchange; Tax Planning and take significant negative effect on earnings management by the company manufacturingindustry sector property and real estate listed on the Stock Exchange.

The results also supported by the phenomena that earnings management practices are commonplace in a way to minimize income through deferred tax expense and recognition of income or expense to shift the tax planning to avoid taxes. Some of the limitations contained in this study are: first, the study examined only one sector within manufacturing companies namely property and real estate sector. Second, the study period was limited to 5 years, from 2011 to 2015. Based on some of the limitations in this study, the research will be expected to use other types of industry to determine the effect of the variables studied in other types broader industry; extending the period of study in order to obtain the possibility of other studies are limited in this study due to its short period of research. 


\section{References}

Barus, Andreani Caroline and Setiawati, Kiki. (2015). "Pengaruh Asimetri Informasi, Mekanisme Corporate Governance, dan Beban Pajak Tangguhan Terhadap Manajemen Laba," Jurnal Wira Ekonomi Mikroskil, Volume 5, Nomor 01.

Bettinazzi, E.L.M., Zollo, M. (2017). "Stakeholder Orientation and Acquisition Performance," Strategic Management Journal 38 (12), pp. 2465-2485.

Brown, B.P., Mohan, M., Eric Boyd, D. (2017). “Top Management Attention to Trade Shows and Firm Performance: A Relationship Marketing Perspective.” Journal of Business Research 81, pp. 40-50.

Burgstahler, David C., and Ilia D. Dichev. (1997). "Earnings Management to Avoid Earnings Decreases and Losses," Journal of Accounting and Economics,Vol. 24, pp. 99-126.

Chiwamit, P., Modell, S., Scapens, R.W. (2017). "Regulation and Adaptation of Management Accounting Innovations: The Case of Economic Value added in Thai State-Owned Enterprises," Management Accounting Research 37, pp. 30-48.

Dhamija, S., Arora, R.K. (2017). "Initial and After-Market Performance of SME IPOs in India,” Global Business Review 18 (6), pp. 1536-1551.

Dhaneswari, Nadia and Thistle, Retnaningtyas. (2013). "Pengaruh Asimetri Informasi, Ukuran Perusahaan dan Beban Pajak Tangguhan Terhadap Praktik Manajemen Laba di Perusahaan Manufaktur Terdaftar di Bursa Efek Indonesia (BEI) 2010-2012,” Tax \& Accounting Review, Vol. 3, No.2.

Dickinson, P., Adams, J. (2017). Values in Evaluation - The Use of Rubrics.

Evaluation and Program Planning 65, pp. 113-116.

Gao, J., O’Sullivan, N., Sherman, M. (2017). "Performance Persistence 
in Chinese Securities Investment Funds," Research in International Business and Finance 42, pp. 1467-1477.

Gianni, M., Gotzamani, K.., Tsiotras, G. (2017). Multiple Perspectives on Integrated Management Systems and Corporate Sustainability Performance. Journal of Cleaner Production 168, pp. 1297-1311.

Ikatan Akuntan Indonesia. (2013). PSAK No.46 tentang Pajak Penghasilan. http://tempdata.iaiglobal.or.id/

Kianto, A., Saenz, J., Aramburu, N. (2017). "Knowledge-Based Human Resource Management Practices, Intellectual Capital and Innovation," Journal of Business Research 81, pp. 11-20.

Hasanah, Lutfatul. (2014). "Pengaruh beban pajak tangguhan, perencanaan pajak dan profitabilitas terhadap manajemen laba industri makanan dan minuman yang terdaftar di BEI 2010-2014," Skripsi. Universitas Esa Unggul.

Meiseberg, B., Mignonac, K., Perrigot, R., El Akremi, A. (2017), "Performance Implications of Centrality in Franchisee Advice Networks," Managerial and Decision Economics 38 (8), pp. $1227-$ 1236.

Phillips, John., M. Pincus and S. Rego. (2003). "Earnings Management: New Evidence Based on Deferred Tax Expense," The Accounting Review, Vol 78, pp.491 - 521.

Rahmi, Aulia. (2013). "Kemampuan Beban Pajak Tangguhan dan Beban Pajak Kini Dalam Mendeteksi Manajemen Laba pada Saat Seasoned Equity Offerings," Jurnal Akuntansi, Vol 1, No 3.

Rehman, M.U. (2017). "Dynamics of Co-Movements among Implied Volatility, Policy Uncertainty and Market Performance," Global Business Review 18 (6), pp. 1478-1487.

Suandy, Erly. (2013). Perencanaan Pajak. Jakarta: Salemba Empat.

Ulfah, Yana. (2013). Pengaruh Beban Pajak Tangguhan dan Perencanaan 
214 Warsono

Pajak Terhadap Praktik Manajemen Laba. Prosiding Simposium Nasional Perpajakan 4.

Waluyo. (2014). Akuntansi Pajak. Jakarta: Salemba Empat. 


\section{Shirkah Author Guidelines}

Shirkah currently offers two routes to submit manuscripts. We highly recommend to submit the articles which are made using OJS (Open Journal System). Feel free register as author soon through visiting http:// shirkah.or.id/index.php/home/user/register. The authors may directly send their manuscripts, along with their resume, to shirkahiainsurakarta@ gmail.com. Please prepare your manuscripts, using following guidelines:

1. Manuscript must be written in English. Submitted articles should not have been published or be under review for publication with another journal.

2. Manuscript's length is about $15-20$ pages, typed in one-half spaced on A4-paper size.

3. Manuscript must include an $150-200$ word abstract and keywords.

4. Manuscript must be arranged as follows: Title, Name of Author, E-mail address, Abstract, Keywords, Introduction (including method if any), Discussion, Conclusion, References.

5. Manuscript's titles not more than ten words.

6. Manuscript must be submitted in Microsoft Word or RTF.

7. Arabic words should be transliterated according to the style of International Journal of Middle Eastern Studies.

8. Manuscript references are preferably derived from the up-to-date references.

9. The author's resume should be submitted separately, consisting of at least full name, institutional address, phone number, areas of studies, and recent publications (if any).

10. Shirkab use APA Style 6th edition (2010) as reference format writing. We suggest the use of a reference manager software such as Mendeley, Zotero, and Endnote at templating the citation style. APA Style to be used is as follows: 


\section{Book with single author}

Swann, G. M. Peter. (2014). The Economics of Innovation an Introduction. Cheltenhum \& Northampton: Edward Elgar.

in-text citation: (Swann, 2014)

\section{Articles in reference books}

Alatas, S. F. (2006). Islam and the Science of Economics in Abu Rabi', I.M. The Blackwell Companion to Contemporary Islamic Thought. USA: Willey-Blackwell (pp. 587-606).

in text citation: (Alatas, 2006)

\section{E-Book}

Hackett, Rosalind (2007). "Religous Dimentions of War and Peace: Introduction.” Dalam Gerrie ter Haar dan Yoshio Tsuruoka (Ed.), Religion and Society: An Agenda for the 21st Century (h. 3-6). Retrieved from http:// brill.nl.

in text citation: (Hackett, 2006)

\section{Master's thesis, from a commercial database}

McNieI, D. S. (2006). Meaning through narrative: A personal narrative discussing growing up with an alcoholic mother (Master's thesis). Available from ProQuest Dissertations and Theses database. (UMI No. 1434728)

in text citation: (Mc Niel, 2006)

\section{Doctoral dissertation, from an institutional database}

Adams, R. J. (1973). Building a foundation for evaluation of instruction in higher education and continuing education (Doctoral dissertation). Retrieved from http://www.ohiolink.edu/etd/

in text citation: (Adams, 1973) 


\section{Doctoral dissertation, from the web}

Bruckman, A. (1997). MOOSE Crossing: Construction, community, and learning in a networked virtual world for kids (Doctoral dissertation, Massachusetts Institute of Technology). Retrieved from http:/www-static. cc.gatech.edu/--asb/thesis/

in text citation: (Bruckman, 1997)

\section{Journal article with No DOI}

Bourkhis, K., and Nabi, M. S. (2013). Islamic and conventional banks' soundness during the 2007-2008 financial crisis. Journal Metrics, 22(2), 68-77.

in-text citation: (Bourkhis \& Nabi, 2013).

\section{Journal article with DOI}

Ichwan, M. (2012). The Local Politics Of Orthodoxy: The Majelis Ulama Indonesia in the Post-New Order Banten. Journal Of Indonesian Islam, 6(1), 166-194. doi:http://dx.doi.org/10.15642/JIIS.2012.6.1.166-194

In text citation : (Ichwan, 2012)

\section{Abstract as citation}

Hasan, N. (2012). Islamist Party, Electoral Politics And Da'wah Mobilization Among Youth : The Prosperous Justice Party (PKS) in Indonesia. Journal of Indonesian Islam, 6(1), 17-47. Abstract from http:// jiis.uinsby.ac.id/index.php/jiis/article/view/97

in text citation : (Hasan, 2012)

\section{Mass media article}

Sahal, Akhmad (2014, March 2). Kiai Sahal dan Realisme Fikih.Tempo Magazine, p. 120.

in text citation : (Sahal, 2014) 


\section{Research report}

Fisher, B. S., Cullen, F. T., \& Turner, M. G. (2000). The Sexual Victimization of College Women. Research Report.

in text citation : (Fisher, Cullen, Turner, 2000)

\section{Monograph}

Routray, Bibhu Prasad (2013), National Security Decision-Making in India (RSIS Monograph No. 27). Singapura: Rajaratnam School of International Studies.

in text citation : (Routray, 2013)

\section{Proceeding article}

Sudibyakto, Hizbaron, D.R., \& Jati, R (Ed.) (2009), Proceeding International Seminar Disaster Theory, Research and Policy. International seminar held by Sekolah Pascasarjana, Universitas Gajahmada, Yogyakarta, 8-9 Desember 2009.

in text citation : (sudibyakto and Jati, 2009)

\section{Paper conference/seminar/symposium}

Janutama, Herman Sinung (2011). "Kraton dan Hubungan Antar Agama." Paper presented in Seminar Kraton dan Panatagama held by Center for the Study of Islam and Social Transformation (CISForm), Yogyakarta, 17 November.

in text citation :(Janutama, 2011)

\section{Online article in web}

Shiva, (2006, February). Bioethics: A Third World Issue. Native-web. Diperoleh dari http://www.nativeweb.org/ pages/legal/shiva.html

in text citation : (Shiva, 2006) 


\section{Online research report}

Kessy, S. S. A., \& Urio, F M. (2006). The contribution of microfinance institutions to poverty reduction in Tanzania (Research Report No. 06.3). Retrieved from Research on Poverty Alleviation website: http://www. repoa.or.tz /documents_storage/Publications/Reports/06.3_Kessy_and_ Urio.pcif

in text citation : (kessy and urion, 2006)

\section{Holy book}

Qur an, $2(25)$

In text citation : (Q. al-Baqarah 2:25).

\section{Encyclopaedia}

Graycar, Adam (1992). Social Welfare Policy. Dalam Mary Hawkesworth dan Maurice Kogan (Ed.), Encyclopedia of Government and Politics (Vol. 1). London: Routledge.

in text citation : (Graycar, 1992)

\section{Interview}

Sultan Hamengkubuwono X (interview, 2011, April 19)

in text citation: (Hamengkubuwono, 2011)

\section{Documentary film}

Steijlen, Fridus (2008). A Day in the Life of Indonesia [documentary film, 58 minutes]. Leiden: KITLV Press.

in text citation : (Steijlen, 2008) 
Vol. 2 No. 2, May - August 2017 